STUDIA I PRACE WYDZIAŁU NAUK EKONOMICZNYCH I ZARZĄDZANIA nr 41, t. 2

\author{
Izabela Klepacka-Dunajko* \\ Halina Kałuża** \\ Uniwersytet Przyrodniczo-Humanistyczny w Siedlcach
}

\title{
WSKAŹNIK PRZEDSIĘBIORCZOŚCI A BEZROBOCIE W POLSCE WSCHODNIEJ W LATACH 2007-2013
}

\section{Streszczenie}

W artykule przedstawiono wyniki badań dotyczące tendencji zatrudnienia w przedsiębiorstwach sektora MŚP na obszarze Polski Wschodniej w latach 20072013 oraz związku między stopą bezrobocia a dynamiką zatrudnienia i wskaźnikiem przedsiębiorczości w świetle danych Głównego Urzędu Statystycznego. Wskaźnik przedsiębiorczości został określony jako liczba podmiotów gospodarczych zarejestrowanych w systemie REGON w przeliczeniu na 10 tysięcy ludności w wieku produkcyjnym. Stwierdzono, że występuje statystyczna zależność między zatrudnieniem, bezrobociem i wskaźnikiem przedsiębiorczości.

Słowa kluczowe: przedsiębiorczość, Polska Wschodnia, zatrudnienie, bezrobocie

\section{Wprowadzenie}

Przedsiębiorstwa sektora MŚP są postrzegane jako determinanta rozwoju współczesnej gospodarki. Są popularną formą prowadzenia działalności gospodarczej ze względu na prostą strukturę organizacyjną, szybkość procesu decyzyjnego, istotny wkład w tworzenie miejsc pracy i ogólny rozwój gospodarczy. Wpływ

* E-mail: Izabela.Klepacka@interia.pl

** E-mail: halina.kaluza@interia.pl 
przedsiębiorstw mikro i małych na gospodarkę jest szczególnie widoczny w zakresie polityki zatrudnienia.

Zdolność zatrudnienia współczesnej polskiej gospodarki jest zdeterminowana głównie przez przedsiębiorczość i małe podmioty¹. Przedsiębiorczość jest procesem kreowania czegoś nowego i wartościowego, z założeniem osobistego ryzyka finansowego, psychicznego i społecznego, a także z założeniem rekompensaty pieniężnej i osobistej satysfakcji².

Najbardziej interesującą funkcją przedsiębiorczości jest zdolność tworzenia nowych miejsc pracy, alokacji i zarządzania zasobami ludzkimi. Każde nowe przedsiębiorstwo poza inwestycją i zarządzaniem kapitałem łączy się ze wzrostem zatrudnienia, a co za tym idzie - spadkiem bezrobocia. Jednym z głównych zabiegów stymulujących rozwój społeczno-gospodarczy jest pobudzanie przedsiębiorczości poprzez stworzenie dogodnych warunków funkcjonowania przedsiębiorstw. Jednak dla rozwoju przedsiębiorczości nie wystarczą tylko dogodne warunki ekonomiczne, potrzebna jest również odpowiednia polityka państwa sprzyjająca podejmowaniu działalności gospodarczej³

Europejska Strategia Zatrudnienia opiera się na przekonaniu, że wyższy poziom zatrudnienia można osiągnąć, promując zachowania przedsiębiorcze i rozwijając system wsparcia sektora małych i średnich przedsiębiorstw.

Drugi filar polityki zatrudnienia UE wywodzi się właśnie z założenia, że stworzenie większej liczby lepszych miejsc pracy wymaga korzystnego klimatu dla rozwoju przedsiębiorczości. Strategia rozwoju regionu, aktywna postawa władz lokalnych to główne czynniki społeczno-gospodarcze wpływające na poziom rozwoju przedsiębiorczości w danym regionie.

Pojęcie bezrobocia w połowie lat 90. XIX wieku w sensie przymusowej bezczynności zawodowej wprowadził angielski ekonomista Hobson. Współczesna literatura ekonomiczna podkreśla trzy cechy osoby bezrobotnej: pozostająca bez pracy, poszukująca pracy i gotowa do pracy ${ }^{4}$.

Według Głównego Urzędu Statystycznego osoba bezrobotna to osoba w wieku od 15 do 74 lat, która w okresie badanego tygodnia nie była osobą pracującą, aktywnie poszukiwała pracy i była gotowa podjąć pracę w tygodniu badania i następnym. Do bezrobotnych zaliczają się także osoby, które nie poszukiwały

1 M. Kabaj, Promowanie zatrudnienia przez rozwój małych i średnich przedsiębiorstw, w: Małe $i$ średnie przedsiębiorstwa w gospodarce, red. J. Klicha, Instytut Spraw Publicznych, Warszawa 2000, s. 106.

2 R.D. Hisrich, M.P. Pater, Entrepreneurship. Starting, developing and managing a new enterprise, IRWING, Boston 1992, s. 10.

3 Encyklopedia biznesu, red. W. Pomykało, Fundacja Innowacja, Warszawa 1995, s. 682.

4 E. Kwiatkowski, Bezrobocie. Podstawy teoretyczne, Wydawnictwo Naukowe PWN, Warszawa 2007, s. 13. 
pracy, ponieważ oczekiwały na podjęcie pracy, którą miały już obiecaną, ale oczekiwały na jej podjęcie nie dłużej niż trzy miesiące i były w gotowości, by tę pracę podjąć. Do bezrobotnych nie zalicza się kształcących się w systemie szkolnictwa $\mathrm{w}$ trybie dziennym ${ }^{5}$. Zgodnie $\mathrm{z}$ art. 2 ust. 2 pkt 2 Ustawy o promocji zatrudnienia i instytucjach rynku pracy pod pojęciem bezrobotnego należy rozumieć osobę niezatrudnioną i niewykonującą innej pracy zarobkowej, zdolną i gotową do podjęcia zatrudnienia w pełnym wymiarze czasu pracy obowiązującym w danym zawodzie lub służbie albo innej pracy zarobkowej, zarejestrowaną we właściwym dla miejsca zameldowania stałego lub czasowego powiatowym urzędzie pracy oraz poszukującą zatrudnienia lub innej pracy zarobkowej ${ }^{6}$.

Niniejsze opracowanie ma na celu przedstawienie tendencji zatrudnienia w przedsiębiorstwach sektora MŚP na obszarze Polski Wschodniej w latach 2007-2013 oraz ustalenie statystycznych zależności między stopą bezrobocia a dynamiką zatrudnienia i wskaźnikiem przedsiębiorczości.

Przedmiotem opracowania jest analiza stanu zatrudnienia i rozwoju przedsiębiorczości w makroregionie Polski Wschodniej w świetle danych Głównego Urzędu Statystycznego. Analiza uwzględnia specyfikę całego regionu i poszczególnych województw wchodzących w jego skład: lubelskiego, podlaskiego, podkarpackiego, świętokrzyskiego i warmińsko-mazurskiego. W zależności od dostępności danych źródłowych badaniem objęto lata 2007-2013.

\section{Charakterystyka Polski Wschodniej}

Województwa Polski Wschodniej należą do najsłabiej rozwiniętych regionów w Polsce i całej Unii Europejskiej, co stanowi przesłankę utworzenia w latach 2007-2013 i 2014-2020 specjalnego funduszu dla pięciu najbiedniejszych regionów, które wykazują najniższe PKB na mieszkańca w poszerzonej Unii Europejskiej.

Granica badanego regionu przebiega wzdłuż Wisły z wyłączeniem strefy wpływów Warszawy. Województwa te zajmują 31,7\% powierzchni kraju i są zamieszkiwane przez 21\% ludności w Polsce. Region Polski Wschodniej graniczy z Litwą, Rosją, Białorusią, Ukrainą i Słowacją .

Główny Urząd Statystyczny, www.stat.gov.pl [dostęp 20.04.2015].

6 Ustawa z 20 kwietnia 2004 r. o promocji zatrudnienia i instytucjach rynku pracy, DzU 2004, nr 99, poz. 1001 oraz DzU 2008, nr 69, poz. 415; nr 70, poz. 416.

Polska Wschodnia. Determinanty rozwoju, red. B. Plawgo, WSAP, Białystok 2006, s. 9.

8 Program Operacyjny Rozwój Polski Wschodniej 2007-2013, Narodowa Strategia Spójności, Narodowe Strategiczne Ramy Odniesienia 2007-2013, MRR, Warszawa 2.10.2007, s. 11 oraz Rocznik demograficzny 


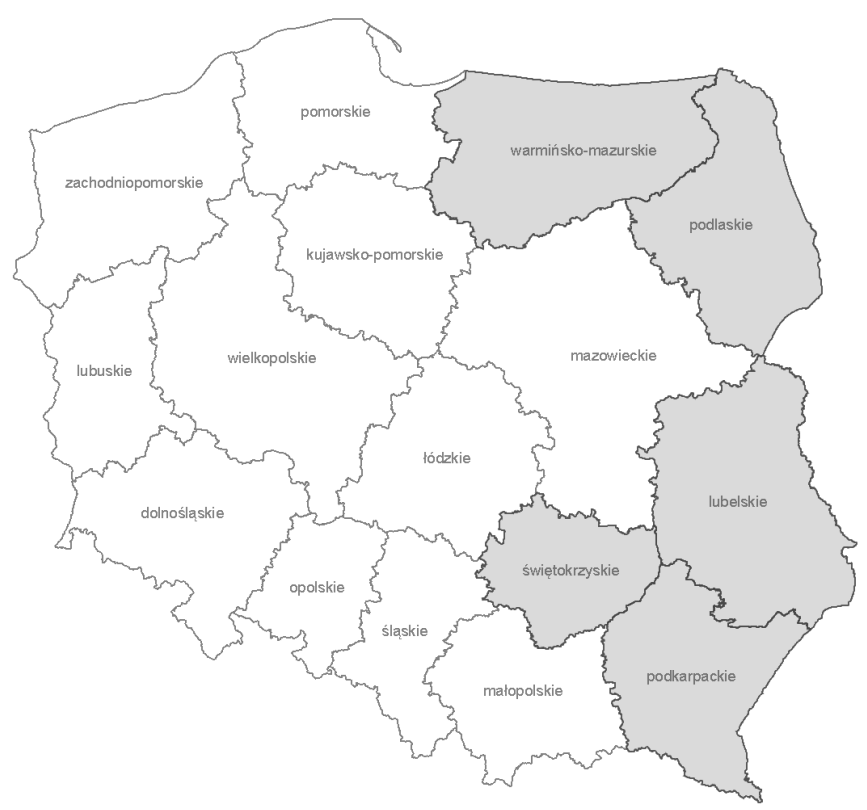

Rysunek 1. Mapa Polski z podziałem na Polskę Wschodnią z uwzględnieniem województw Źródło: www.geo.stat.gov.pl [dostęp 20.04.2015].

Rynek pracy Polski Wschodniej w stosunku do rynków kraju i europejskich charakteryzuje się najniższym poziomem zatrudnienia i aktywności zawodowej, a także najwyższym wskaźnikiem bezrobocia. Według Borkowskiego bezrobocie w UE ma charakter koniunkturalny, a w Polsce strukturalny9. Związane jest to przede wszystkim $\mathrm{z}$ dysproporcjami rozwojowymi w układzie przestrzennym i niedostosowaniem podaży pracy do popytu na nią. W tabeli 1 przedstawiono stopę bezrobocia rejestrowanego na terenach Polski Wschodniej w poszczególnych latach. Najwyższą stopą bezrobocia charakteryzuje się województwo warmińsko-mazurskie, jednak największe pogorszenie się stanu rynku pracy występuje w województwie podlaskim.

$9 \quad$ Polski rynek pracy wobec integracji europejskiej. Raport IPiSS, red. S. Borkowski, Zeszyt nr 24, Warszawa 2003, s. 55. 
Tabela1. Stopa bezrobocia rejestrowanego według województw Polski Wschodniej w latach 2007-2013 (\%)

\begin{tabular}{|l|r|r|r|r|r|r|r|}
\hline \multirow{2}{*}{ Jednostka terytorialna } & \multicolumn{7}{|c|}{ Ogółem } \\
\cline { 2 - 9 } & 2007 & 2008 & 2009 & 2010 & 2011 & 2012 & 2013 \\
\hline Lubelskie & 13,0 & 11,2 & 12,9 & 13,1 & 13,2 & 14,2 & 14,4 \\
\hline Podkarpackie & 14,2 & 13.0 & 15,9 & 15,4 & 15,5 & 16,4 & 16,3 \\
\hline Podlaskie & 10,4 & 9,7 & 12,8 & 13,8 & 14,1 & 14,7 & 15,1 \\
\hline Świętokrzyskie & 14,9 & 13,7 & 15,1 & 15,2 & 15,2 & 16,0 & 16,6 \\
\hline Warmińsko-mazurskie & 18,7 & 16,8 & 20,7 & 20,0 & 20,2 & 21,3 & 21,6 \\
\hline
\end{tabular}

Źródło: opracowanie własne na podstawie danych GUS.

Stopę bezrobocia rejestrowanego obliczono jako stosunek liczby bezrobotnych zarejestrowanych do liczby cywilnej ludności aktywnej zawodowo. Stopę bezrobocia podaje się $\mathrm{z}$ uwzględnieniem pracujących $\mathrm{w}$ gospodarstwach indywidualnych w rolnictwie (będących składową cywilnej ludności aktywnej zawodowo) oszacowanych na podstawie wyników: w latach 2004 do listopada 2010 - Narodowego Spisu Powszechnego Ludności i Mieszkań 2002 oraz Powszechnego Spisu Rolnego 2002, a od grudnia 2010 - Powszechnego Spisu Rolnego $2010^{10}$. Powierzchnia obszarów wiejskich Polski Wschodniej zajmuje 32,5\% ogółu całej powierzchni wiejskich kraju. W tym regionie występuje wyższy udział obszarów wiejskich w relacji do powierzchni ogółem niż w pozostałych rejonach kraju i wynosi $95,7 \%$ (od 97,5\% w województwie warmińsko-mazurskim do 93,7\% w województwie podkarpackim) wobec $93,2 \%$ przeciętnie w kraju (tabela 2 ).

Tabela 2. Powierzchnia ogółem oraz powierzchnia obszarów wiejskich

\begin{tabular}{|l|c|c|c|}
\hline \multicolumn{1}{|c|}{ Województwo } & Ogółem & Obszary wiejskie & $\begin{array}{c}\text { Udział obszarów wiejskich } \\
\text { w powierzchni ogółem (\%) }\end{array}$ \\
\hline Lubelskie & 25122 & 24159 & 96,17 \\
\hline Podkarpackie & 17845 & 16724 & 93,72 \\
\hline Podlaskie & 20187 & 19256 & 95,39 \\
\hline Świętokrzyskie & 11711 & 11042 & 94,29 \\
\hline Warmińsko-mazurskie & 24174 & 23577 & 97,53 \\
\hline
\end{tabular}

Źródło: opracowanie własne na podstawie danych GUS.

10 GUS, www.stat.gov.pl [dostęp 20.04.2015]. 
Wraz z rozwojem społeczno-gospodarczym kraju tereny wiejskie rozwijają się wielofunkcyjnie, większa grupa rolników podejmuje działalność pozarolniczą, podejmując pracę zarobkową najemną lub świadcząc usługi. Pozarolnicze zatrudnienie ma szczególne znaczenie w procesie rozwoju Polski Wschodniej. Powstawanie nowych miejsc pracy wiąże się przede wszystkim z rozwojem sektora małych i średnich przedsiębiorstw.

\section{Metody analizy}

W pracy przedstawiono wyniki badań dotyczących zależności pomiędzy wartością wskaźnika przedsiębiorczości a stopą bezrobocia i dynamiką zatrudnienia na obszarach Polski Wschodniej. Wskaźnik przedsiębiorczości wyrażono liczbą podmiotów gospodarczych zarejestrowanych w systemie REGON w przeliczeniu na 10000 mieszkańców w wieku produkcyjnym. Wzór wyrażono za pomocą następującej formuły ${ }^{11}$ :

gdzie:

$$
W p=\frac{P}{L} \times 10000
$$

$W p$ - wskaźnik przedsiębiorczości;

$P$ - liczba zarejestrowanych podmiotów gospodarczych;

$L$ - liczba ludności w wieku produkcyjnym.

W celu określenia zależności pomiędzy wartością wskaźnika przedsiębiorczości a zatrudnieniem i bezrobociem przeprowadzono analizę korelacji Pearsona.

Badanie przeprowadzono na podstawie danych dotyczących województw: warmińsko-mazurskiego, podlaskiego, lubelskiego, podkarpackiego i świętokrzyskiego, pochodzących z Banku Danych Lokalnych Głównego Urzędu Statystycznego. W procedurze obliczania wykorzystano dane statystyczne z lat 2007-2013.

\section{Wyniki badań}

Obliczono wskaźnik przedsiębiorczości za okres 2007-2013 dla województw makroregionu Polski Wschodniej (tabela 3). Województwa te charakteryzują się najniższym PKB na mieszkańca w Polsce ${ }^{12}$.

\footnotetext{
11 M. Iwańska, W. Bieńkowska, Zróżnicowanie wartości wskaźnika przedsiębiorczości w gminach wiejskich województwa mazowieckiego w układzie przestrzennym, Acta Scientiarum Polonorum Oeconomia 9 (3), SGGW, Warszawa.

12 GUS, www.stat.gov.pl [dostęp 20.04.2015].
} 
Tabela 3. Wskaźnik przedsiębiorczości w województwach Polski Wschodniej w latach 2007-2013

\begin{tabular}{|l|r|r|r|r|r|r|r|}
\hline \multirow{2}{*}{ Jednostka terytorialna } & \multicolumn{7}{|c|}{ Ogółem } \\
\cline { 2 - 9 } & 2007 & 2008 & 2009 & 2010 & 2011 & 2012 & 2013 \\
\hline Lubelskie & 1117,0 & 1137,2 & 1147,4 & 1191,1 & 1181,3 & 1216,7 & 1255,2 \\
\hline Podkarpackie & 1073,7 & 1082,1 & 1080,8 & 1123,1 & 1110,8 & 1140,3 & 1177,6 \\
\hline Podlaskie & 1185,8 & 1200,8 & 1187,9 & 1201,2 & 1199,6 & 1241,0 & 1270,6 \\
\hline Świętokrzyskie & 1327,4 & 1344,2 & 1309,6 & 1332,5 & 1305,8 & 1342,1 & 1377,2 \\
\hline Warmińsko-mazurskie & 1223,3 & 1248,2 & 1234,8 & 1252,0 & 1236,1 & 1271,8 & 1306,2 \\
\hline
\end{tabular}

Źródło: obliczenia własne na podstawie danych GUS.

Zauważalny jest niewielki wzrost wskaźnika przedsiębiorczości w ciągu analizowanych lat w każdym z badanych województw. Przodujące jest województwo świętokrzyskie z najwyższym wskaźnikiem przedsiębiorczości zarówno w 2007, jak i 2013 roku. Jednak największą dynamiką wzrostu charakteryzuje się województwo lubelskie (rysunek 1). Związane jest to ze znacznym rozwojem społeczno-gospodarczym.

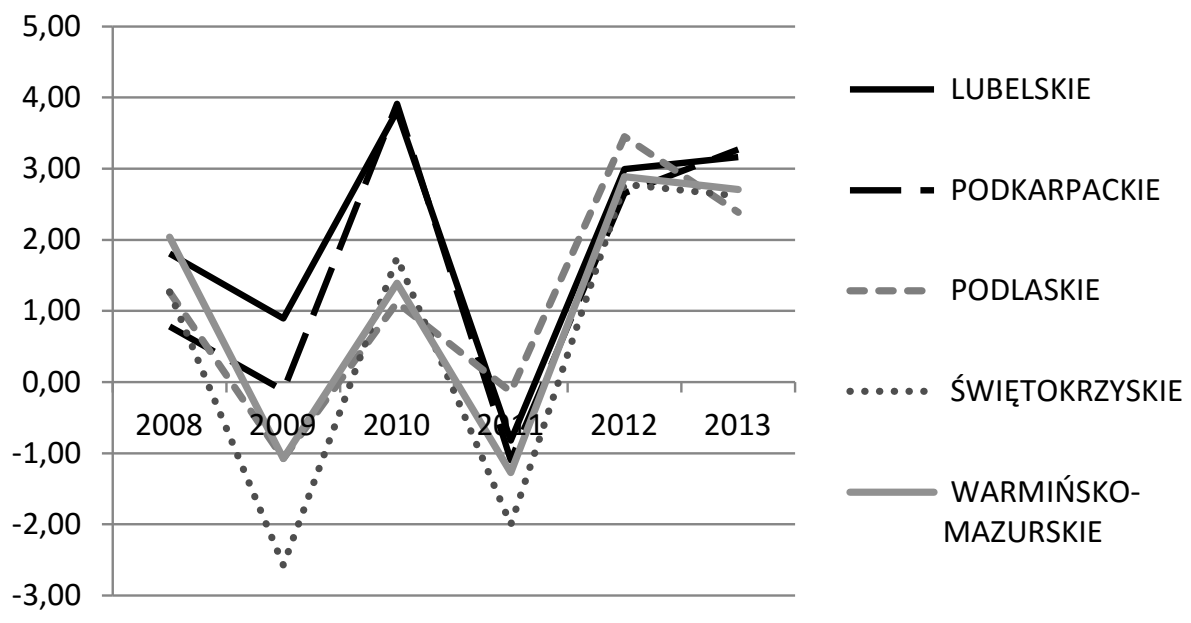

Rysunek 1. Dynamika wzrostu wskaźnika przedsiębiorczości makroregionu Polska Wschodnia Źródło: obliczenia własne na podstawie danych GUS. 
W gospodarce rynkowej duże znaczenie dla wzrostu popytu na pracę ma sektor MŚP. W Polsce zdecydowana większość przedsiębiorstw należy do tego sektora, zatrudniając: do 9 osób - mikro; 10-49 osób - małe; 50-249 osób - średnie.

Sytuację rynku pracy na terenach wiejskich ilustruje także zestawienie stopy bezrobocia, średniej powierzchni użytków rolnych oraz stopnia urbanizacji według województw (tabela 4).

Tabela 4. Porównanie regionalnego zróżnicowania zatrudnienia w rolnictwie, stopy bezrobocia, wielkości gospodarstw oraz stopnia urbanizacji

\begin{tabular}{|l|c|c|c|c|}
\hline Województwo & $\begin{array}{c}\text { Odsetek } \\
\text { pracujących } \\
\text { w rolnictwie }\end{array}$ & $\begin{array}{c}\text { Średnia } \\
\text { powierzchnia } \\
\text { użytków rolnych } \\
\text { w gospodarstwie } \\
\text { ha }\end{array}$ & $\begin{array}{c}\text { Stopa } \\
\text { bezrobocia } \\
(\%)\end{array}$ & $\begin{array}{c}\text { Stopień } \\
\text { urbanizacji } \\
\text { (\% ludności } \\
\text { w miastach) }\end{array}$ \\
\hline Lubelskie & 36,6 & 7,4 & 13,1 & 46,5 \\
\hline Podkarpackie & 23,8 & 4,5 & 15,4 & 41,2 \\
\hline Podlaskie & 33,9 & 12,1 & 13,8 & 60,2 \\
\hline Świętokrzyskie & 26,5 & 5,4 & 15,2 & 45,2 \\
\hline $\begin{array}{l}\text { Warmińsko- } \\
\text {-mazurskie }\end{array}$ & 16,2 & 23,0 & 20,0 & 59,9 \\
\hline
\end{tabular}

Źródło: opracowanie własne na podstawie danych GUS.

To porównanie pokazuje, jak duże znaczenie dla kształtowania sytuacji gospodarstw na małym obszarze ma rozwój infrastruktury i pozarolniczego zatrudnienia. Istotne znaczenie dla rozwoju województwa ma lokalizacja ośrodka gospodarczego. W tabeli 5 można zauważyć, że w województwie lubelskim, z największym ośrodkiem gospodarczym, jakim jest Lublin, zamieszkanym przez 343598 mieszkańców i skupiającym prawie 35\% ludności województwa, odnotowano najniższą stopę bezrobocia w Polsce Wschodniej. Natomiast w województwach warmińsko-mazurskim, z największym ośrodkiem gospodarczym Olsztynem (174 675 mieszkańców), w którym mieszka 20,6\% ogólnej liczby mieszkańców województwa, oraz w podkarpackim, gdzie największym ośrodkiem miejskim jest Rzeszów (183 108 mieszkańców), skupiający 20,0\% ogólnej liczby mieszkańców województwa - stopa bezrobocia jest najwyższa.

W celu zbadania siły współzależności dwóch zmiennych: stopy bezrobocia i wskaźnika przedsiębiorczości oraz wskaźnika zatrudnienia ludności w wieku produkcyjnym i wskaźnika przedsiębiorczości, policzono współczynniki korelacji. 
Tabela 5. Współczynnik korelacji Pearsona dla stopy bezrobocia oraz liczby zatrudnionych w wieku produkcyjnych i wskaźnika przedsiębiorczości w latach 2007-2013

\begin{tabular}{|l|c|c|}
\hline \multirow{2}{*}{ Województwo } & $\begin{array}{c}\text { Wskaźnik zatrudnienia w wieku } \\
\text { produkcyjnym a wskaźnik } \\
\text { przedsiębiorczości }\end{array}$ & $\begin{array}{c}\text { Stopa bezrobocia a wskaźnik } \\
\text { przedsiębiorczości }\end{array}$ \\
\cline { 2 - 3 } & 0,81 & 0,77 \\
\hline Pobelskie & $-0,63$ & 0,92 \\
\hline Podkarpackie & 0,34 & 0,46 \\
\hline Świętokrzyskie & $-0,05$ & 0,09 \\
\hline Warmińsko-mazurskie & $-0,35$ & 0,53 \\
\hline
\end{tabular}

Źródło: opracowanie własne na podstawie danych GUS.

Analizując otrzymane wyniki w poszczególnych województwach, można zaobserwować dużą rozbieżność. Między wskaźnikiem zatrudnienia (wyrażonym udziałem procentowym osób zatrudnionych w wieku produkcyjnym do ogółu osób w wieku produkcyjnym) a wskaźnikiem przedsiębiorczości występuje silna zależność w województwie lubelskim. Oznacza to, że wraz z rosnącą liczbą zatrudnionych osób w wieku produkcyjnym zwiększa się liczba przedsiębiorstw. W województwie podkarpackim występuje dość duża ujemna zależność, co oznacza wzrost wskaźnika przedsiębiorczości, a spadek liczby osób zatrudnionych w wieku produkcyjnym. Może to świadczyć o zakładaniu nowych działalności gospodarczych przez osoby zarejestrowane w Urzędzie Pracy. Brak korelacji liniowej występuje w województwie świętokrzyskim, a w województwie podlaskim i warmińsko-mazurskim występuje bardzo słaba współzależność między dwoma zmiennymi.

Z powyższych obliczeń wynika, że w ciągu analizowanych lat, tj. 20072013, zaobserwowano znaczącą korelację pomiędzy wzrostem stopy bezrobocia rejestrowanego i równoczesnym wzrostem wskaźnika przedsiębiorczości w województwie lubelskim, podlaskim, podkarpackim i warmińsko-mazurskim. Oznacza to, że wraz ze wzrostem liczby osób bezrobotnych liczba przedsiębiorstw się zwiększa. Być może zarejestrowane w systemie REGON przedsiębiorstwa nie są aktywne (niewyrejestrowane), stąd rozbieżność między analizowanymi zmiennymi. W ostatnim okresie popularną formą prowadzenia działalności gospodarczej jest samozatrudnienie. Przejście pracownika na własny rachunek redukuje obciążenia pozapłacowymi kosztami pracy przedsiębiorstwa borykające się z problemami finansowymi. Rozwój samozatrudnienia ma też niebagatelne znaczenie z punktu widzenia bezrobocia. Osobom poszukującym zatrudnienia stwarza dodatkową możliwość powrotu do zasobu pracujących. 
Ta forma działalności gospodarczej w początkowym okresie jej prowadzenia często nie przekłada się na tworzenie nowych miejsc pracy dla osób bezrobotnych. Z przeprowadzonych analiz wynika, że wyjątkiem jest województwo świętokrzyskie, gdzie nie występuje współzależność między dwoma zmiennymi, tj. liczbą bezrobotnych i liczbą przedsiębiorstw.

\section{Podsumowanie}

Sektor małych i średnich przedsiębiorstw pełni wiele istotnych funkcji - społecznych, politycznych, gospodarczych. Odgrywa istotną rolę w kreowaniu przedsiębiorczych postaw, a także dają szansę i możliwość zarówno samozatrudnienia, jak i wzrostu zatrudnienia.

Ograniczenie bezrobocia jest uzależnione od poziomu przedsiębiorczości oraz otoczenia prawnego, finansowego i społecznego małych i średnich firm. Badania przeprowadzone na podstawie materiału statystycznego wykazały, że zauważalny jest niewielki wzrost wskaźnika przedsiębiorczości w ciągu analizowanych lat w każdym z badanych województw. Przodujące jest województwo świętokrzyskie z najwyższym wskaźnikiem przedsiębiorczości zarówno w 2007, jak i 2013 roku, jednak największą dynamiką wzrostu charakteryzuje się województwo lubelskie.

Jak wynika z przeprowadzonych analiz między zatrudnieniem, bezrobociem i wskaźnikiem przedsiębiorczości istnieje związek chociaż niekoniecznie proporcjonalny. W analizowanych latach, tj. 2007-2013, zaobserwowano znaczącą korelację pomiędzy wzrostem stopy bezrobocia rejestrowanego i równoczesnym wzrostem wskaźnika przedsiębiorczości w województwie lubelskim, podlaskim, podkarpackim i warmińsko-mazurskim. Oznacza to, że wraz ze wzrostem liczby osób bezrobotnych liczba przedsiębiorstw się zwiększa, wyjątkiem jest województwo świętokrzyskie, gdzie nie występuje współzależność między tymi dwoma zmiennymi.

\section{Literatura}

Encyklopedia biznesu, red. W. Pomykało, Fundacja Innowacja, Warszawa 1995.

Hisrich R.D., Pater M.P., Entrepreneurship. Starting, developing and managing a new enterprise, Boston 1992.

Iwańska M., Bieńkowska W., Zróżnicowanie wartośi wskaźnika przedsiębiorczości w gminach wiejskich województwa mazowieckiego w układzie przestrzennym, Acta Scientiarum Polonorum Oeconomia 9(3), SGGW, Warszawa. 
Kabaj M., Promowanie zatrudnienia przez rozwój małych i średnich przedsiębiorstw, w: Małe i średnie przedsiębiorstwa w gospodarce, red. J. Klicha, Instytut Spraw Publicznych, Warszawa 2000.

Kwiatkowski E., Bezrobocie. Podstawy teoretyczne, Wydawnictwo Naukowe PWN, Warszawa 2007.

Polska Wschodnia. Determinanty rozwoju, red. B. Plawgo, WSAP, Białystok 2006.

Polski rynek pracy wobec integracji europejskiej. Raport IPiSS, red. S. Borkowski, Zeszyt nr 24, Warszawa 2003.

Program Operacyjny Rozwój Polski Wschodniej 2007-2013, Narodowa Strategia Spójności, Narodowe Strategiczne Ramy Odniesienia 2007-2013, MRR, Warszawa 2.10.2007.

Rocznik demograficzny 2010, GUS, Warszawa 2011.

Ustawa z 20 kwietnia 2004 r. o promocji zatrudnienia i instytucjach rynku pracy, DzU 2004, nr 99, poz. 1001 oraz DzU 2008, nr 69, poz. 415, nr 70, poz. 416.

Źródła internetowe

www.geo.stat.gov.pl

www.stat.gov.pl

\title{
THE ENTREPRENEURSHIP INDICATOR VALUE AND UNEPLOYMENT IN THE EAST POLAND 2007-2013
}

\begin{abstract}
The article presents results of the research on employment trends in the SME sector in the area of Eastern Polish 2007-2013, and the relationship between the unemployment rate and the dynamics of employment and entrepreneurship in the light indicator data of the Central Statistical Office. The entrepreneurship indicator was resented as a number of registered in the REGON system for 10 thousand inhabitants in the production age. A statistically significant dependency was found between the of employment, unemployment and entrepreneurship indicator.
\end{abstract}

Translated by Izabela Klepacka-Dunajko, Halina Katuża

Keywords: entrepreneurship, East Poland, employment, unemployment

JEL codes: R11, R12 
